\title{
Editorial: Racism, Xenophobia and Development
}

\author{
WENDY HARCOURT
}

Too often mainstream development skirts around the tricky realities of racism and xenophobia or fear of the 'other'. Such discussions happen on the margins of development policy circles. They are not quite what one wants to air in debates on economics and trade or high-level state matters. Even the 'soft' topics of education and health rarely consider such difficult to measure realities. Ironically, even when racism gets on the development agenda, it tends to slip off. The outcome of a vibrant UN World Conference on Racism held in September 2001 was eclipsed totally by the events that happened in New York just three days after it concluded. ${ }^{1}$

Ironically, given the lack of impact of that Conference, September 11 and the aftermath of the 'war on terror' has much do with the growing xenophobia and deeply entrenched racism with which development is imbued. As Ben Pitcher explains in his article, part of the problem is that the very language we use in international relations and development negotiations is couched as if general openness and tolerance prevails. Such a pretense masks the fears and racism that even the most liberal of Europeans (and their descendents in dominant white populations around the world) often harbour. From assumptions about 'tribal conflicts' preventing growth of modern nations in sub-Saharan African to intolerance of Islamic women wearing head scarves, to descriptions about youth bulges in urban wastelands of big European cities and elsewhere development discussions are riddled with racism. Essentially, there is a deepseated fear about the potential 'problem' of 'others' - the people who do not fit into the category of well-behaved western European (white, moderately religious Christian, employed, heterosexual and middle class) citizens. The unspoken given is that this is the type of citizen modern development aims to create. Those who are projected as the 'other' in development are rightly concerned that their way of life, their humanity and livelihoods are being run rough shod by such discrimination that does not accord them status or respect. They know and experience commonly held prejudices against their race, religion, creed, ethnicity, class and culture (and gendered expression within their culture) despite the loud proclamations of understanding and awareness. Some indeed, have endured genocidal attacks, which have been haplessly ignored by the development community (as for example in Central Africa) while apparently addressed in human rights policy.

As the journal issue suggests, the level of racism and xenophobic behaviour is evident not only in Europe and other western communities but also in attitudes towards ethnic 
minorities found all around the world. There is globally a prevailing mistrust along with naked exclusions and outright neglect and open attacks on peoples who are perceived as outsiders or a threat to the mainstream. Articles in the issue look at the rise of Islamophobia, the hate attacks on Roma people in Europe and violence against refugees in South Africa; the marginalizing of Palestinians in Israel; the distrust of African migrants in Sweden; the exclusion of indigenous people in Latin America; the neglect of Bushmen in Botswana; the racist policies directed at Aboriginal Australians in Australia; and the inherent racism in the Pacific. The articles capture both the difficulty that people who endure racism face and the courage of those who are trying to end unjust state policies, media misrepresentations and consequent violent behaviour directed against vulnerable and clearly marked 'others'.

The message that emerges from the journal is that racism and xenophobia are hardly new. After all, colonialism in which the roots of development can be found thrived on the exploitation and paternalism of 'others' - both people and natural resources - by those who had the power, money and authority. What is worrying today is that despite all the legal frameworks and social concern expressed, racism and xenophobia are on the rise. Racism is integral to modern life. The numerous media reports are only vaguely dismaying to those whose lives they do not describe. It is cosily assumed that these stories are just blips in modern statehood, all is really okay, the norm is tolerance, liberty and equality. ${ }^{2}$

The articles point to how sadly the norm, despite the rhetoric and comforting assumptions, is far from that. The experiences of indigenous peoples, minority ethnic groups and migrants reveal steady and ongoing racism and xenophobic attacks occur daily in both the Global North and South. Not only is racism found on the streets but also within government institutions. Police forces can be deeply racist and are rightly viewed with great mistrust by many communities, particularly when minority groups are not represented in them. Racism and xenophobia are also central to the military agenda of national and international security.

The point is how to go beyond the fine words and well-meaning policy in order to confront widespread prejudice and hate that is so easily masked. A development based on humanity, respect, rights and tolerance has to unravel how closely development itself is built on a lack of respect and tolerance for other ways of life. It needs to reveal how such wilful ignorance leads to painful misunderstandings and unfair treatment, massive economic and social inequalities and almost inevitably violent conflict as Jan Pronk brings out forcibly in his contribution.

What is compelling in this set of articles is that they do not simply dwell on the violations. They inevitably relate the scandalous results of racist migration policy, the fall out of unconsidered multiculturalism and the violations of the rights of minorities, indigenous people and refugees. But, they go beyond the hype of much media coverage to look at how racism and xenophobia suffuses the language and mindset of development policy. In many ways, this is far more troubling. There may be good policies and legal frameworks, but the mindsets of ordinary people and the development community itself are still to change.

Practitioners and policymakers are too often unseeing of the implications of racism and xenophobia. They fail to confront the impacts of racism, intolerance and xenophobia at all levels of development and modern life. Such failures it seems are hard to counter, but crucial if we are to find justice, peace and tolerance.

Reading the articles, particularly those that relate to Australasia, brought to mind a conversation I had during a recent visit to the Bay of Islands, New Zealand.

In holiday mode, I got chatting with my fellow partakers of a beautiful sea view. Given our differently accented English, we were naturally asking where we came from. One couple came from a town two hours North. They were Maori, a fact I realized when they mentioned their ancestors originally came from Pacific Islands 1,000 years ago. An older woman spoke about being an Irish New Zealander. She had migrated 50 years ago as a 
16-year-old school girl, from Ireland, and spoke about home both in relation to her New Zealand friends and family and her community of Irish friends and family whom she visited when she could. An Australian woman announced that she was Australian born and bred, as opposed to me being an Australian now living in Italy. Her contribution to the conversation rather broke the illusion I had of how well multiculturalism functioned in that part of the world. I was reflecting with them on how integrated Maori culture seemed to be in New Zealand particularly for young people where Maori was the official second language and taught at schools. However, the Australian woman was not so interested in that line of thought and moved onto recommend other holiday places in the Pacific, Fiji being a favourite destination. She confided in us that she goes there regularly. Apparently you can enjoy wonderful weather and outstanding hotels, good food, inexpensive cocktails and fabulous beaches. Her tipoff was not to go out of the hotel until the last day. One has to go out to see something more of the country, and its people of course, but the dire poverty of the people was far too depressing. Better to do it on the last day, otherwise it would ruin your holiday.

The inherent racism in this statement does not need to be elaborated, nor the injustices that lead to development being built on tourism that benefits the tourists and the owners of the industry rather than the people who live by the hotels and no doubt service them. But, what the articles in the journal ask you to do is not dismiss such statements as frivolous or ignorant and blind far removed from the aims of development policy in the Pacific or elsewhere in the Global South. We have to see such attitudes as part and parcel of the same development approach that recommends investments in tourism and service industries. This model of development promotes a grossly uneven type of growth that benefits elites rather than marginalized indigenous peoples. Instead, we need to promote a development that builds sustainable livelihoods, which preserves the environment and provides social and economic benefit for all citizens.
Such attitudes are not harmless. They are at the foundation of ways of seeing that can move swiftly from unthinkingly wanting to avoid the ugly sights of poverty, to anger at such poverty ruining a holiday or your neighbourhood. This attitude can ultimately lead to fears that nameless poor people might want to force their way into your privileged life, and need to be kept away in case they want to harm you or steal your property. Such intolerance lies hand in hand with policies that seek to develop people and nations that promote luxury for some at the expense of other's livelihoods and rights. Development should not be so concerned about whether the resentment of the poor leads to violence and 'failed'states. Rather development should be challenging the assumptions of the well-off who see the lives of 'others', their 'poverty', their sense of 'identity' or 'culture' as something to be transformed, if not feared and controlled.

As Linda Burney of the Wiradjuri Nation and Minister for Community Services in New South Wales, Australia states, we are not talking here about clashes between the first world capitalist economy with third world communitarian societies. There are no big issues requiring big solutions.

'The time for all-encompassing solutions is past ... Too many reports have been written and shelved. The basic problem is that it involves a lot of hard work, with probably few results until years have passed ... consultation is needed, ongoing dialogue between participants, because the people affected will not cooperate if they are not part of the process ...'

Following Burney's own contribution working with Australia's disadvantaged but nevertheless thriving Aboriginal culture, all of us need to take incremental steps towards ending racism and xenophobia. This requires the development community to change itself and recognize that western ways of seeing needs to open up to different cultures. Without succumbing to a romanticism of culture, development needs to be inclusive of 'others', adapting to political and economic landscapes with flexibility and resilience so that all can participate. 


\section{Development 52(4): Upfront}

Notes

1 The World Conference against Racism, Racial Discrimination, Xenophobia and Related Intolerance was held in Durban, South Africa from 31 August to September 2001. See the official website http://www.un.org/WCAR. The statement of the NGOs who met at the Durban Review Conference held in Geneva April 2009 is published in this issue's Last Word. For more details on the Durban Review Conference resolutions, see http://www.un.org/ durbanreview 2009.

2 Some might well argue that now the United States has a Black President and racism is no longer; but as Andrew Manis warns in the Macon Telegraph, published in Georgia, USA, in January 2009, there is a virulent and open hostility of US white 'racist loud mouths' towards President Obama. See www.clarksvilleonline.com/tag/ dr-andrew-manis. 